\title{
Daoism and Ecology-An Interview with James Miller
}

\section{道家思想与生态学 : 詹姆士・米勒访谈}

\author{
Stephen K. Levine
}

The European Graduate School, Switzerland

\begin{abstract}
The interview focuses on James Miller's thinking about the relation between Daoism and ecology. Miller believes that, to develop a foundation for ecological sustainability, we need to break down the separation between human beings and the world we live in. This can be done by Daoist techniques of bodily cultivation, based on the concept of the body as porous and interpenetrating with the environment. Practices such as these will lay the groundwork for an aesthetic foundation of ecology.
\end{abstract}

Keywords: China, Daoism, ecology, Qi, bodily cultivation, tong 通 (interpenetration), aesthetic transformation

\section{摘要}

此次访谈聚焦于詹姆士.米勒 (James Miller)对道家思想与生态学关联性的思考。米勒相 信，为了构建生态可持续性发展，我们需要打破人类与居住环境彼此分离的状态。依托 于人体与自然互通互联，互相依存的观念，道家修身的方法能实现天人合一的平衡。这 些 ( 道家传统的 ) 践行方式将为生态美学奠定根基。

关键词: 中国，道家思想，生态学，气，修身，通 (互通互联)，美学转化

Stephen K. Levine (SKL): Your recent book, China's Green Religion: Daoism and the Quest for a Sustainable Future, brings together your thinking on religion, Chinese culture, and ecological sustainability. Can you tell our readers how your background and experience led you to develop in this direction?

James Miller (JM): My work on Chinese religions and ecology goes back twenty years to when I was a graduate student. I attended a conference at Harvard on Daoism and Ecology and was so taken by the experience that I became the coeditor of the conference proceedings, published by Harvard University's Center for the Study of World Religions in 2001. Since then I have continued my work on religion and nature in China.

SKL: Your recent writing focuses on the problem of the relationship between human beings and nature. What do you see as the main problem in the Western conception of this relationship? How do aspects of traditional Chinese culture offer us an alternative to our usual way of thinking about nature? 
JM: Of course it's hard to generalize about a "Western" conception of nature, but I think it is fair to say that Western modernity established its dominance when a chain of binary dichotomies coalesced in the social imagination. These binary categoriesmodern/primitive, science/religion, Europe/non-Europe, White/non-White, mind/ nature, spirit/matter, human/animal and culture/nature - have come to define our modern approach to nature and environment. Chinese approaches founded in yin-yang thinking are much more conducive to an integrated approach to thinking about ecology.

SKL: You use Daoism, specifically the concept of Qi, as a framework that can help us reconceive our thinking about ecological sustainability. What is it about the Daoist tradition that enables us to do that?

JM: Qi refers to the life principle or vital energy that animates the cosmos. All things are comprised of Qi and thereby have a connection to and influence upon all other beings. This means that ethical principles about life are not confined to the human world (do not steal), but also to the nonhuman world (do not pollute waters). These principles have been enshrined in Daoist ethical codes going back some 1500-2000 years.

SKL: You emphasize that we need not only a theoretical transformation but a practical one, based on bodily cultivation. How can we achieve this?

JM: Daoist cultivation techniques are based on paying attention to the flow of Qi in and through the body. The starting point is being aware of one's own breath. Anything we can do to break down the distinction between the inside and outside of our bodies is valuable.

SKL: You have written about the Daoist notion of a porous body and of nature as spontaneous and self-transforming. Can you say more about this? Are there tendencies in contemporary Western thought that bring us closer to this perspective?

JM: One of the key concepts that I elaborate in the book is that of tong 通, which can be translated as pervasion or interpenetration. Basically, it is a key Daoist term that indicates that the body and the cosmos are mutually interpenetrating. The body is fundamentally defined by its nine orifices, and if we think of the skin as a porous membrane on top of that, then we can begin to visualize ourselves as constantly processing energy and material from "outside." So rather than think of the body as a static object which changes slowly over time, and the environment as a collection of another set of static objects that also change slowly over time, think of the body and the world together as a set of mutually interpenetrating dynamics of matter and energy. This view shares some similarities with the vitalism of Western thinkers such as Bergson. It also emphasizes the primacy of the body, similar to the thinking of Merleau-Ponty.

SKL: Since our journal has the mission of building bridges between East and West through the practice of the arts, it would be of particular interest if you explain the aesthetic dimension of the kind of transformation you envisage. How is the aesthetic dimension tied to your conception of the body's porous relationship to the world?

JM: The aesthetic dimension is the foundation for ecological transformation. The way that we perceive, sense, and experience the natural world in relation to our own bodies is fundamentally an aesthetic activity. From this aesthetic foundation we then develop the ethics and politics to transform our world into an ecologically flourishing one. 
SKL: Can you tell us what constitutes an aesthetic foundation in your view? How can we transform our bodily experience of the world in such a way that it can serve the process of ecological transformation? Are there specific Daoist disciplines to do this?

JM: Yes, there are many Daoist practices that in my view aim towards the integration of the inner body with the cosmic body. These are done with the goal of producing a transcendent or immortal body for the Daoist practitioner. I'm not interested in these religious disciplines per se, but rather the underlying aesthetic principle that it is possible through embodied ritual and meditative practice to change one's perception of the world. This is important for me because I think that the environmental movement has largely functioned at a legal, political, and scientific level and has failed to engage the mass of ordinary people on an embodied, physical way. This has only started to happen recently as people realize that their own personal health is bound up with the health of the environments that they live in.

SKL: In what way would the transformation of bodily experience to develop an aesthetic relation to the world lead to the kind of ethics and politics that you are speaking of?

JM: When people realize that their own health and livelihood are compromised by pollution and climate change, then this inevitably produces a change in ethics and politics. Too often, however, environmental ethics has followed a quasi-Christian trope of "saving the world" as though the world is something outside of us that needs our care and attention. It is hard to persuade people to think of the "environment" as an object of ethical concern or to organize politics around the transition to sustainability so long as people think of this as something extrinsic to their own interests. But as soon as people realize that sustainability and flourishing are about their own health, wealth, and prosperity, then there is less need to make ethical or political arguments in favor of some imagined idea of care for the earth.

SKL: We usually think of "aesthetics" as the philosophical discipline that studies the arts and their place in human experience. Do you see the arts as having an important role in the kind of transformation of which you speak? Are there examples of this in Chinese culture, e.g., Chinese landscape painting?

JM: I am in favor of all means of helping people to realize that their own life depends on the life of the planet. As I mentioned above, too often, this has been couched in rational, intellectual, scientific arguments. But what this failed to notice is that people's lives are not changed so much by rational argument but by embodied experience. I think that all forms of embodied experience, including the experience of art as a sensual, aesthetic experience, can do an enormous amount to fill in the gaps that science and reason could never fill.

SKL: Contemporary China itself seems to be in an ecological crisis. What tendencies in Chinese culture mitigate against this, if any? Politics in China today operates in a centralized and top-down manner, as opposed to the spontaneity of wu-wei. Can a Daoist perspective on nature be put into practice in such a situation? Can philosophers and artists assist in this transformation and, if so, how?

JM: My students at Duke Kunshan University are deeply concerned about environmental issues because they recognize that their future is being compromised by 
the (in)actions of their parents' generation. I find that they are largely ignorant of anything from traditional Chinese philosophy and religion, except for some conservative Confucian values. Philosophers and artists are key to bringing the power of Daoist values and ideals back to the center of Chinese culture. Frankly, however, this is enormously difficult because the education system is dominated by science, technology, and English language learning. The positive side of this is that there is enormous appetite in China for learning about how Chinese culture can contribute to ecological issues.

\section{About the Author}

Stephen K. Levine, PhD, DSSc, REAT, Founding Dean of the Doctoral Program in Expressive Arts in the Division of Arts, Health and Society at The European Graduate School (Switzerland), Professor Emeritus at York University (Toronto), and Co-Editorin-Chief of the international journal Creative Arts in Education and Therapy-Eastern and Western Perspectives.

Email: slevine.egs.edu@gmail.com

\section{About the Interviewee}

James Miller, PhD, a leading authority on Chinese religion and ecology, is Professor of Humanities at Duke Kunshan University, Chair of the Division of Arts and Humanities, and Co-Director of the Humanities Research Center.

Email: j.e.miller@dukekunshan.edu.cn 